\title{
(息)
}

Citation:

Moss, D and Richter, I (2011) Changing times of feminism and higher education: From community to employability. Gender and Education, 23 (2). 137 - 151. ISSN 0954-0253 DOI: https://doi.org/10.1080/09540251003674113

Link to Leeds Beckett Repository record:

https://eprints.leedsbeckett.ac.uk/id/eprint/317/

Document Version:

Article (Accepted Version)

The aim of the Leeds Beckett Repository is to provide open access to our research, as required by funder policies and permitted by publishers and copyright law.

The Leeds Beckett repository holds a wide range of publications, each of which has been checked for copyright and the relevant embargo period has been applied by the Research Services team.

We operate on a standard take-down policy. If you are the author or publisher of an output and you would like it removed from the repository, please contact us and we will investigate on a case-by-case basis.

Each thesis in the repository has been cleared where necessary by the author for third party copyright. If you would like a thesis to be removed from the repository or believe there is an issue with copyright, please contact us on openaccess@leedsbeckett.ac.uk and we will investigate on a case-by-case basis. 
Changing times of feminism and higher education: from

community to employability

\begin{abstract}
This article discusses the creation of space and time for feminist approaches in higher education in the context of shifting community and employment relations and the restructuring of higher education space-time. It draws on the reflections of three feminist academics concerning aspects of their work biographies in two very different higher education settings. It explores the shift from working in an academic department concerned with community studies to one concerned with education and related employment. The article focuses on the attempt to sustain feminist practices through these changing times and settings and is informed by the work on time and space by Barbara Adam, Henri Lefebvre and Doreen Massey.
\end{abstract}

Space; time; feminism; higher-education 


\section{Changing Times of Feminism and Higher Education: from Community to Employability}

\section{Introduction}

This article draws on the reflections of three feminist academics to explore the spatial and temporal influences on their work; in particular the shift from a community to an employability orientation in higher education. The focus is on the perceptions of 'insiders' living with the effects of institutional change and the changing space-time of higher education (Adam 2002). The work considered in the article concerns two departments within two institutions, one with a community studies orientation (2002) and one with an education and employability orientation (2008). In both departments, academic studies related to children, young people and society. This article, considers our movement through higher education and the impact of space-time restructuring. It is difficult to separate these influences. As Massey argues $(2005,55)$

...neither time nor space is reducible to the other; they are distinct. They are, however, co-implicated. On the side of space, there is the integral temporality of dynamic simultaneity. On the side of time, there is the necessary production of change through practices of interrelation. 
The relationship between feminism and academia is not straightforward. As argued previously (Moss and Pryke 2007), academics are involved in work related to course development, administration, teaching, placements and research. Each academic has a different balance of work. One aspect may be consciously informed by feminist beliefs and another not. The influence each academic has relates to status, position, reputation, role, personal history, political allegiances, length of service and so forth (Henry 2007). In addition,

Academic feminist approaches vary in relation to the use of concepts of 'gender' and 'women'; the use of integrationist and separatist practice; the nature of alliances with struggles related also to class, colour, 'race,' ability, nationality, heterosexuality and age (Moss and Pryke 2007,368).

Feminism within academia involves a series of evolving ideas, desires for the future and academic practices in relation to gendered inequality. Kristeva (1981) alerts us to the ways those claiming feminism may easily be caught up in reproducing relations of oppression. The pursuit of equality may be based on limited understanding of social power and social change. She reveals the complex ways in which radical action may be incorporated by other interests unless complex systems and processes of inequality related to gender are thoroughly understood and unpicked. In our experience deep seated gendered inequalities continue to be reproduced through higher education and we are involved in these processes. Sexualized differences are relied on, advanced and reconstructed in ways that suit particular political, economic and professional interests (Haug 1992). It is important, as indicated by Kristeva (1981), to be 
radical and reflexive in considering how these deep seated power relations inform our everyday academic work.

This article explores some of these complex and competing pressures in relation to our feminist work in higher education. Firstly we discuss the methodological approach and key concepts informing the article. Secondly we explore our experiences at the respective academic institutions, highlighting particular spatial and temporal influences and gendered relations. Thirdly we reflect on the changes that we experienced and how we attempted to sustain feminist practices and agendas through these changing times and settings.

\section{Methodology and key concepts}

The research discussed in this article has evolved over time. The article builds on a conference paper (Moss and Pryke 2004), a publication that was delayed for three years because of transition in employment (Moss and Pryke 2007) and a presentation at a Time and Higher Education Symposium (Moss 2009). Spatial and temporal influences on academic experience are complex, dynamic and interwoven. The methodology informing this paper has therefore also evolved. It is not possible to go back in time and modify the research approach from 2002 in the light of our learning and experience since that time. We have built on this earlier work as ideas and concepts have evolved in our field and as our 
academic lives have changed. We reflect on theoretical understanding of space and time in order to analyse and illuminate our concrete experiences of change.

As feminists involved in academic areas concerned with children and young people we have been caught up in spatial and temporal restructuring at a macro level re-shaping both higher education and the workforce. The course we reflected on in 2002 and the related department have closed, considered financially inefficient. The course we were involved in in 2008 was one of many that had burgeoned to meet workforce needs and changing political and economic priorities. Hence our personal academic biographies and journeys reflect changing political and higher education priorities over time.

The article is based on a series of reflections gathered over a period of time. The first set of reflections $(2002)^{1}$ draw on a reflexive log which was written during a period of $\mathrm{PhD}$ research. The reflections from this period are also based on an academic diary. Reflections were written in relation to diarised events. These earlier reflections concern our everyday experience at a community college where we were involved in providing higher education in a department of community studies. The second set of reflections (2008) came out of a series of conversations related to space, time and academic experience in an education department in a 'new' university. The two academics concerned wrote individual reflections from these conversations. In both periods the reflections concerned different areas of academic responsibility including research, course 
development and teaching. In both cases the academic focus related to children, young people and society.

Both sets of reflections are intended to capture the everyday experience of academic work, including critical events and turning points. Adam $(2002,7)$ argues there is a need to connect understanding of 'network society' to 'the base of everyday practice and lived experience'. Our understanding of higher education accords with Smith $(2002,21)$, who conceives of it '... as arising in people's activities (what they do, say, write and so on) in particular local settings at particular times'. It is important to try and capture some of the daily, face to face academic work we have been involved in, in order to clearly illuminate the effects of spatial and temporal change, the forms of feminist engagement and ultimately the ways feminist understanding and strategy may be strengthened. Some feminist work is valued in parts of higher education but some may involve 'shadowlands' of practice. Here we have to work in,

... the paradox spaces that are part and parcel of the industrial logic of risk, [where] women the world over are implementing moral codes and practices ... (Adam 2002, 10)

Following Massey (2005) and Lefebvre (1991) we conceptualise higher education space as socially produced and as a site of struggle involving major systems of power and inequality related to class, gender and other social divisions. Following Adam (1998) we conceptualise higher education time as involving several meanings and as socialised in relation to benchmarks that suit some interests more than others. From this understanding, we draw on three 
sensitising concepts related to space and time. These concepts reveal different aspects of everyday academic experience and provide insight into the changing frameworks and guidelines shaping higher education and our involvement with these.

The first concept, 'space-time practices' draws attention to the overarching frameworks and institutional practices of higher education (Lefebvre 1991). Lefebvre's concept of 'spatial practices' focuses on everyday routes through space-time related to changing forms of capitalism. This idea is developed with reference to Barbara Adam's $(2006,123)$ work on time,

When the invariable time of the clock is imposed on living systems, it tends to be the living systems that are required to adapt to the machine-time rather than the other way round.

Adam's $(2002,15)$ analysis demonstrates that time is created to 'human design.' Time spent on certain activities in higher education is commodified in particular ways and this involves attempts to impose control. In the process, aspects of human experience remain uncommodified, hence under-valued in the dominant order of things. These 'shadowlands' of higher education often relate to human relationships and care (ibid, 9),

...it is the time values and the social relations of industrial time that are being adopted as well as imposed...To be 'modern', progressive' and even civilised means to embrace the industrial approach to time (Adam 2003, 71). 
As feminists we may attempt to address aspects of inequality that are less visible in the power structures of higher education, but some of this work may be 'decontextualised' (ibid p.17), or seen as marginal in relation to the evolving system imperatives (Habermas 1981/1987). The changing 'space-time practices' of higher education provide new frameworks for our academic work that have their own gendered priorities. In the process we may be caught up in reproducing new forms of gendered inequality.

The second concept 'space-time representations' draws attention to symbols, signs and the changing meanings related to gender that inform and are generated through the spaces of higher education (Lefebvre 1991). The concept draws deeper attention to the ways gender is constructed through our everyday academic work. As time passes and as we move through different settings, new constructions of gender inform our progress. Dominant ideas related to gender quickly become fossilised in the curricula (Halbwachs 1925/1992), for example, ideas about the absence of male role models in family life. Practices that rely on 'naturalised' divisions of care, for example the gendered divisions represented in the children's workforce, may settle into the processes of higher education in new ways (Kristeva 1981, Cameron, Mooney and Moss 2002, Lewis 2003, Cameron 2004, Moss 2006) and begin to operate as dominant clichés (Haug 1992). New academic disciplines find favour, whilst others fade. Ideas about 'difference,' 'inclusion', 'employability', 'faith' and 'enterprise' may become 'buzz words'; signs that the academy is vibrant and socially engaged whilst at the same time academic attention to major social and gendered inequalities may be squeezed. 
The meaning of higher education continuously changes and academic time is colonised in different ways. This colonisation extends higher education's '...econo-political reach into, as well as the ab/use of the past and future' (Adam 2003,72 ). The progress of students (who may be conceptualised as investments in the future) is crafted in ways that relate to wider gendered socio-political interests. As particular futures are designed for students, employment areas outside higher education are corralled into service through concepts of 'partnership' and other devices. Attention to the everyday ways we conceptualise and construct gender in our academic work reveals the changing 'space-time guidelines' we are working to,

Here what we might have called representation is no longer a process of fixing, but an element in a continuous production; a part of it all, and itself constantly becoming (Massey 2005, 28).

The third concept we draw on 'centres of action' comes from the work of Adam (1990) and is linked to Lefebvre's (1991) concept of 'representational space'. The concept draws attention to the way higher education space-time is lived in the everyday. In this article we use the concept to focus particularly on the ways we have tried to actively carve out space and time for feminist approaches within higher education. Our academic work is conceptualised as lived space-time. We operate in present time, imagine future time and draw on past times to practice higher education (Jaques 1982/1990). We live through complex rhythms and weave complex spatial and temporal influences (Adam 
1990, Davies 1990). The concept 'centres of action' reveals the concrete ways we conduct our everyday work within changing times and settings and our attempts to sustain feminist practices.

Together, the three space-time concepts discussed above are intended to reveal different facets of changing academic experience, including the higher education frameworks we work within, the changing guidelines (related to gender) that we follow and how as individuals we create space-time for our feminist concerns. We now draw on these concepts to consider our academic work in two different settings at two different times.

\section{Higher education: space, time and community}

\section{Gendered frameworks 2002}

In 2002, all of us worked in a college of higher education, in an academic department concerned with community and young people, two of us on a course concerned with accessing welfare rights. The academic work in this setting focused on community involvement to redress social inequalities. The department attracted students from the local multi-racial and working class communities. The course, Social and Legal Studies, ${ }^{2}$ was a joint degree, shared with another department. The first reflection below relates to this programme. The second relates to feminist doctoral research that one of us was engaged in at the time. She was researching the ways that women students created space and time for academic work. The reflections below are intended to draw attention to 
some of the gendered implications of the higher education frameworks we were working to.

There is a continuous ... tension between the two departments running the joint degree .... They have different approaches to learning and teaching, for example, the Legal Studies teaching requires much learning by rote.... My students are mainly working-class and women who are more accustomed to the teaching style of my department which adopts a problem-posing reflective approach ... As the lead department, our Community Studies department ${ }^{3}$ has to challenge Legal Studies in some areas of response to students. I arrange and attend meeting with both heads of department to try to resolve differences (Pryke 2002).

The dominant temporal rationales of higher education shape my $[\mathrm{PhD}]$ progress in particular ways. There is flexibility as to when each stage should be completed but the order of completion is more problematic, in particular the transfer from MPhil to PhD. This is based on a model of progress in research that assumes students to be working at one level and then upgrading to another. The reality is that I work at the same level from the outset and this causes difficulties. The model of research informing the transfer documentation is still of empirically based scientific research of a deductive nature ...With approval from my supervisors, my own research does not follow this model as I shift between the literature, research data and analysis throughout the process (Moss 2002).

In terms of course development and teaching we were positioned in a particular niche providing higher education in a principally working class community. The work was tied to different vocational routes. The particular (joint) course we had developed was intended to attract non-traditional students to both traditional (law) and new (community) forms of academic study. The more 
established area of law still operated on traditional pedagogic lines (exam based, large lectures, rote learning). The community development ethos in our part of the college involved more participative learning. Working class women we had recruited were caught up in evolving and competing academic frameworks and systems.

In terms of research, the higher education frameworks we worked to generated similar tensions. Research monitoring was being centralised and was dominated by those who applied more traditional research approaches. Systems to encourage qualitative and feminist research were also being developed and were recruiting students. One system undermined the other, in particular feminist supervision and feminist research, leaving particular students caught up in these competing influences between older and newer academic research frameworks.

Both reflections provide examples of evolving gendered relations in higher education and highlight the position of women students and feminist staff at particular times and in particular places. Whilst as feminists we might have helped students to navigate a way through these systems we were also involved in their production, having drawn students into the institution and designed courses for them.

\section{Gendered guidelines 2002}

Both authors of the 2002 reflections had come into higher education from feminist work in the voluntary sector. One had worked in advocacy and women's refuges; one, in feminist community work. The reflections below demonstrate the 
attempts to incorporate this understanding and experience into the higher education work of student support and research and illuminate the gendered guidelines of higher education we were working through,

I use my experience of work on relationship abuse to support a student who has fled the family home ... I receive a phone call from her; she is on a bus on her way into college which she sees as an initial safe place. I talk immediately to our security, and then discuss the issues with my head of department who authorizes any action necessary and offers direct support to the student when she arrives ...The student and I find a women's refuge able to take her immediately and I drive her to the safe contact point (Pryke 2002).

Particular academic writers are very difficult to understand at the time that I read them ...I do not have the knowledge they are drawing on. There is a tradition within academic culture that involves a belief in expert knowledge, that is, that it is possible to 'master' a particular academic discipline in its entirety. The process of engaging with knowledge through texts in a way that is backwards in time, leads me to feel a loss of connection with both feminist ideas and with women students themselves even though feminist writers and women students have provided pathways to this earlier writing (Moss 2002).

These reflections reveal the complex and competing gender guidelines that we worked through. In relation to the student facing violence, it was a taken for granted assumption within this higher education space-time that we had a responsibility to make sure women students were safe. The community ethos which was shared by the head of department meant priority was given to social inequality and related barriers to learning. This had not always been the case in this department. For a period of time staff had had to justify work related to violence against women as a legitimate part of community work and related 
higher education. But by the time of these reflections, this local space-time of higher education provided unquestioning support.

In the same period of time, but in the higher education space related to research, more tensions were encountered in relation to gender guidelines. Different perspectives on gender were encountered through academic reading and speaking to women students. Although many of the bodies of knowledge drawn on were initially feminist, historical reading led away from this. Layers of meaning from past times had to be understood, negotiated, resisted or incorporated for the research to progress. This process began to create distance from the experiences of women students.

\section{Carving out space-time for feminism 2002}

The complex gendered frameworks and guidelines of higher education generated particular space-time for our everyday work in which we tried to sustain feminist practices. As 'centres of action' our academic work had to be carved from these arrangements and perspectives. Below, Julie reflects on how she developed a learning space with women students and Dorothy reflects on a research approach intended to keep women's interests at the foreground,

In relation to violence against women students, I talk to my head of department and suggest setting up a discreet support group. Women students of South Asian heritage are to be the initial group, simply because a higher number of them are approaching me. 
The aim will be to allow the students to survive external pressures and continue their studies successfully. The head of department allocates time and small budget ... Women in the group share issues, offer suggestions for ways forward as well as support, maintain confidentiality and generally relax and become more comfortable and less isolated around the issues (Pryke 2002).

Foregrounding women students ${ }^{4}$ experiences is made easier by adopting flexible research methods. These change and adapt in relation to continuously arising feminist and occupational concerns. For example, I deviate from the selected sample in order to respond to the emotional concerns of women respondents ...As problems with particular research issues arise, women students become collaborators in pursuit of research answers ... Kelly tells me she has talked to a student who had been ostracised by many, including staff, for racist behaviour, "I thought by doing that with him he altered quite a lot ... sometimes tutors just back down a lot, where in fact they should get more involved in the actual situation....Because he would have looked at it completely different (Moss 2002).

The learning space that Julie developed became a temporary part of the higher education practice at the college. Women students were facilitated to assert some control. The research approach that Dorothy developed allowed for compromise, change and review and built on feminist approaches that both facilitated critical thinking, but also reflection and openness to both academic and non-academic perspectives (Hill Collins 1990). The community ethos of our academic department enabled the feminist approaches we developed but whilst there was clear evidence of feminist commitment in our academic work, we were also involved in creating other outcomes for students that were less visible and 
equally significant. We had recruited working class women to a particular niche of higher education and had set other processes in train in relation to their prospects for the future and the particular careers they might take. Intending to enable them, we were also involved in imagining their future (Adam 2006) shaping pathways that may have generated lower wages than other higher education routes. Their very entry to higher education had altered the gendered dynamics of their family lives and some of the hostility they were experiencing in their families may well have been associated with this (Edwards 1993). As academics we were positioning our students in particular ways. This process becomes even more visible as we discuss our higher education experience in 2008.

Higher education: space, time and employability

\section{Gendered frameworks 2008}

By 2008 two of us worked at a new university in the area of childhood and youth, in an Education department. This was a growth area in higher education, hence, a port of call for us when our jobs at the college (above) were in jeopardy. Our experience of academic work in relation to young people (above) made us employable in this new area. Many young working class women came on the course 'Childhood and Youth Studies', from families with little experience of higher education (Osgood 2005). The two reflections below are intended to capture the 
gendered implications of the new higher education frameworks we found ourselves working to,

Timetabling and rooming is out of our hands. There is no flexibility because of the constant increase in student numbers. In induction week students are queuing up outside rooms because the rooms are too small, or the rooms don't have the equipment we need, or rooms have been double-booked. One student (first year) approaches to say she has epilepsy. I discuss disability services, she says she is not disabled, just wants me to know. Others approach with other difficulties such as, children to pick up from school, paid work obligations. Could I save materials for them from the induction session they will miss? I respond could they ask a friend to collect for the papers, "But I don't have a friend yet - I don't know anyone yet..." There are over 100 students in the first year (3 are young men) and the number of staff has not risen (Moss 2008).

The key thing that bothers me is that rather than improving women's conditions of employment in relation to equal pay and status, the changes in the children's workforce that are coming through pay lip service to improving women's position through training and qualifications. This is not a serious attempt to look at important issues related to the children's workforce. It feels superficial. Part of the policy is finding work for women who are 'unemployed' - single parents - 'welfare to work'. My PhD is looking at the connections and untangling what is happening between the children's workforce restructuring, higher education and other social policy (Richter 2008).

This new space-time of higher education presented us with an immediate challenge. In the past, many of these young women would have continued in further education and then entered quite low paid jobs with children. Now they were accumulating the debts of higher education with an uncertain benefit. The growth of childhood related courses in higher education reflected and responded 
to wider social and political changes. Firstly, changing political priorities included the professionalisation of work in the early years and the restructuring of the children's workforce (Moss 2006, Lewis 2003, Cameron, Mooney and Moss 2002, Cameron 2004). This required workers to be educated to a higher level. Secondly, the welfare to work agenda developed under New Labour was concerned with welfare benefit reduction and involved pressuring low income mothers to enter the work force (Link and Bibus with Lyons 2000), hence child care became more of a political priority. There was some concern for women's and children's equality but the emphasis was to increase work expectations (ibid). Thirdly the Government's widening participation in higher education agenda (Wolf, Jenkins and Vignoles 2006) meant higher education institutions (with pressure from the Quality Assurance Agency) were imposing a more explicit 'employability' agenda and encouraging the development of related academic courses. These developments generated a very large expansion in higher education courses in the area of childhood. This expansion relied on gendered assumptions about the sorts of (working class) women that would be recruited. Future careers, professional and academic pathways were being imagined for this part of the student market.

The reflections above demonstrate our confusion and concern at the gendered implications of this new higher education space-time. By 2008 we were engaged with the 'massification' of higher education and 'batch teaching,' particularly affecting young working class women, many of whom were the first in their families to enter higher education. The students had been marketed a dream for the future related to a professional career with children, yet had been 
positioned at the cheapest end of higher education provision. The space-time for personal interaction between tutor and student was squeezed. Whilst, as feminist academics, we might have tried to help women to navigate a way through the system, we were also involved in producing these new gendered relations. We were involved in drawing them into higher education in this particular space-time.

\section{Gendered guidelines 2008}

Both of us reflecting in 2008 had worked with young people before entering academia, one in a secure unit and one with girls in the youth service. The new curriculum of childhood and youth integrated the major social sciences. However, by 2008 , more emphasis was put on professional development and employability than in our past academic experience. In 2002, the academic courses involved critical analysis of the professions in relation to professional power and the implications for service users. Because we were educating community workers, the emphasis had been on challenge and critique. In 2008 the focus was on skill building and reflection related to future employability in the children's workforce. Whilst these developments restricted the space for feminism related to teaching, feminist guidelines for research were much more established in the university. Feminist academics were positioned more influentially in the institution. The reflections below capture some of our everyday experiences related to the evolving and diverging gender guidelines we were encountering in our academic lives, 
I am beginning to feel removed from the young women I teach and frustrated that I can't seem to get my material over. I put them in small groups and they avoid the task and talk about nights out. I also make too many assumptions about their prior knowledge and there are too many of them to get to know properly. When teaching I mention the welfare state; few know what it is. They say they have heard of Nelson Mandela, but many have not heard of apartheid. If I am to engage with students I need to enter their cultural universe (Freire 1972). I don't really want to. I want them to enter mine! I snatch a conversation with two young women who seem distressed. They have found out the young men they share a house with are going to a brothel. I tunnel back in time to the same place and see a desperate need for feminist ideas and research to ease the trauma of their transitions to adulthood (Moss 2008).

I feel very privileged to have been supported by the institution to carry out research (PhD, no fees). I think supporting people to do research and putting the structures in place is absolutely positive and reflects well on the institution. I feel I have had wonderful support from individuals. The minus side is the heavy handed approach to monitoring. I have been inundated with bits of paper which aren't giving me clear information but are part of the process of recording and central monitoring. These bits of paper are very difficult to deal with. Ethics release, for example; there is a lack of clarity and too much information. Overall I can understand why the processes are there, but filling forms in on line is difficult (Richter 2008).

On the one hand, the dominant gender guidelines related to the course we taught on were fairly explicit. The presence of large numbers of young women hoping for careers with children re-asserted fossilised gendered relations of care, despite continued attempts by the staff team to elevate the professional standing of this important group of future workers. Our academic role was to advance the understanding, knowledge and skills of these young women in relation to children 
and childhood; a traditional focus of women's education. The first reflection demonstrates a feeling of distance from the young women students and from the higher education project with which we were engaged. It conveys the relief when it is possible to respond to students' expressed concerns about male power and describes a rare sharing of personal experiences in a crowded class room. The space-time for this sort of inter-personal engagement was very restricted. In 2002 , it had been through such engagements that new gender perspectives could be developed in resistance to the dominant guidelines.

In relation to research, however, by 2008 the gender guidelines were more in tune with our own. There was established feminist research. Supervision was not undermined in the ways experienced in 2002. Space-time for research felt more of a privilege than in 2008. However, the further development of risk management and accountability processes required carefully worded written justifications of research to be submitted to committees and panels that still might follow more restrictive gender guidelines.

\section{Carving out space-time for feminism 2008}

The passing of time in higher education and our movement through space reflected changes in the political climate, in the nature of the student cohorts, in the curricula and higher education setting. The space-time of higher education we moved through included complex and competing frameworks and guidelines related to gender. Some of these were explicitly feminist but some relied on 
archaic ideas about childhood and care. Such developments made us look back to our time at the college with some nostalgia but also with more suspicion in relation to our previous academic practice. It was important to be alert to the unequal gender relations we ourselves were involved in producing. We needed to look more carefully at the future times we were imagining for our students,

As a teaching strategy I rarely bang on about feminism very much. When I'm teaching I use the expression but I disguise it until I can't any longer and then I own up to it. That sounds very feeble, but it's the reverse because I really want to take these young women on this journey to understand feminism and I think they've been taught and conditioned to turn their backs on anything that challenges the status quo, their family, personal relationships or wider relationships. I want to draw them in. There's an idea of what a perfect feminist is (hairy armpits). I want to break down that idea - what does it mean for people's lives? I want to draw them in (Richter 2008).

I feel there is collusion between different institutional and state structures; higher education and policy collusion in relation to young people. Both say they enable betterment for young women, but the childhood workforce changes feed into the cultural contexts of young women on our courses. They don't go on degrees to become doctors or lawyers. They 'know' it's OK for them to 'do' childhood. My role in that process (as a researcher and lecturer) - because I believe in work with children and I believe children deserve a highly qualified, able group of people involved in their lives. If anyone is going to be involved in it I don't want some Tom Dick or Harry. I know my values are good and hope they will get disseminated. I'm highly arrogant! (Richter 2008)

The reflections here are alert to the wider context of women's lives including complex institutional relations, their futures and the futures of the children they will be involved with. We tried to revisit feminism through the eyes of the young 
women we taught, many of whom had been brought up with an 'Illusion of postfeminism' (Coppock, Haydon, and Richter 1995) and an illusion of their own equality in relation to education and the workforce. We recognised the need to examine the gendered implications of work force changes with them. These were changes that were heralded as promising them betterment. There was a need to develop the curriculum in new directions, incorporating a strong feminist dimension where our access allowed, but making sure this feminism was accessible to our students. The politics of gender and the politics of childhood were as closely related, as the politics of 'race,' class and disability. Children also deserved social, economic and political change. Our work on the curricula involved drawing critical attention to the power contained in gender and childhood as conceptual fields and as areas of practice. The research Ingrid became engaged in, involved listening to young women and accompanying them through their higher education experiences into their future work. In these ways we began to carve out space-time for feminist academic practice in relation to both teaching and research. Simultaneously, there is no doubt that we were engaged in higher education and workforce developments that did not necessarily benefit women. Our work was aligned to the gendered divisions of cash and care that were being reasserted in new ways in the labour market.

\section{From community to employability in higher education}


As we navigated changing higher education frameworks and guidelines we were part of a wider process that constructed new and reaffirmed old gender relations. Whilst teaching students to be critical of fossilised representations of gender and trying to develop the means for them to resist these, we also recruited women to particular parts of the academy that might increase their vulnerability in the family and the labour market. The movement from an academic department focusing on community to one more explicitly engaged with employability made this aspect of our role more evident. Higher education practices rely on gendered divisions that suit wider professional and political interests and generate student numbers. By 2008 we were involved in an academic area that ultimately led to 'jobs for the girls' in the low paid sphere of childhood. The space-time within higher education to draw their attention to this and to develop with them alternate strategies was severely limited. Higher education was going through processes of 'modernisation.' This squeezed the space-time for us to work interactively with students to develop critical gender perspectives. Ylijoki (2009) discusses the acceleration of time in academia and $\operatorname{Adam}(2003,67)$ aspects of work modernisation and the related 'compression of time' we were experiencing. For example, we were expected to be engaged in 'Increasing activity within the same unit of time' (ibid). This meant that although numbers of students had increased there had not been associated increases in physical space or staffing so face to face work was restricted. We were required to reorganise, 'the sequence and ordering of activities' (ibid). This involved enforced restructuring of curricula to increase efficiencies and limited our ability to develop new curriculum areas 
related to gender. We were expected to use, 'peaks and troughs more effectively' (ibid), which led to the imposition of set times for teaching in either blocks or sequentially, involving extended hours in the day. This meant the ability to timetable flexibly in relation to the needs of mothers, carers and paid workers was severely restricted. A University partnership agreement led to guaranteed places on the third year of our Childhood and Youth Studies degree for those who had completed related Foundation degrees. This further restricted our control over the curriculum, generated more 'employability' paths and decreased our capacity to engage with women throughout three years of their degree. We were expected to eliminate, 'all unproductive times from the process' (ibid). This involved our space-time being caught up in increased procedures for monitoring, evaluation and audit. Performance review and related benefits and penalties became institutionalised. These changes were accompanied by compulsory staff festivals. Our experiences of higher education in 2008 involved,

...the keepers of time ... determin[ing] festive periods, auspicious and unlucky days as well as right and wrong times for specified activities (Adam 2006, 122).

This modernisation diverted us from developing creative and interactive work with students along feminist lines,

From my perspective such bureaucratisation of teaching cuts deep. It fundamentally alters what teaching can be. It shifts the emphasis from process to product, from contextual doing to outcome-driven rationalised conduct ... More importantly it moves the locus of control and responsibility from the teacher to the system (Adam 2001 p 1). 
The structures of higher education have always been symbiotically related to systems of employment, community, the professions and state. Categories of academic knowledge reflect this (Bourdieu 1968/1991). The association of the older professions (law, medicine) with traditional universities and newer professions such as leisure, tourism, childhood, ICT, with the new universities emerges from these sets of relations. No matter the critical distance that academics feel they have, the relationship between higher education and the society it emerges from and shapes is complex. Our movement from one higher education site to another and our movement in time draw attention to this complexity. Concepts of community informed higher education practice at both sites, but in 2002 they were resonant and shaped curricula and academic feminist responses. In 2008 they were more associated with the market for higher education and ideas about service and future employment. Concepts of employment informed both areas of higher education, but by 2008 they were far more intrusive and imposed new limitations on interaction with students and course development. The contradiction was that by 2008 space-time for feminism in research had grown. The different emphasis of our research, whilst in both cases feminist, reflected our changing experience of higher education. Our research in 2002 explored community, gender and higher education. In 2008 it explored employment, gender and higher education, reflecting the shift in emphasis of the higher education we were engaged in from community to employability. 


\section{Conclusion}

Feminist perspectives and practices were commodified in different ways in the different spaces and times of higher education we experienced. Some aspects were valued within higher education such as work in 2002 related to domestic violence and research in 2008 related to women students and the children's workforce. Both these pieces of feminist academic work were institutionally (including financially) supported. However, some areas of our work remained invisible or were viewed as marginal in the modernisation and employability trajectory of higher education (Adam 2006, 124). By 2008, the scope to influence the student academic experience by addressing feminist concerns across the curriculum was such an area. This is revealed through some of our everyday reflections from that period. Drawing on our everyday academic experiences uncovers,

...from the standpoint of people located in a definite institutional site, the progressive despoiling of people's local and particularising control over their everyday lives as the expansion of the ruling relations continually displaces and expropriates their self and mutually generated relations, their own knowledge, judgement and will (Smith 2002, 39).

By 2008 we experienced the space- time of teaching and learning in higher education as colonised through the growth of ties to politicised employment and welfare agendas (and organisations). This had major implications for women as workers, students and as benefit recipients. Our academic work involved producing future workers for the children's workforce with all the potential gendered inequality involved. This workforce would in all 
likelihood remain relatively low paid. One major political intention was to compel lone mothers to enter paid work and put their children into child-care rather than look after them at home. We feared the continued low status and struggles of women despite the promises of betterment and we feared the continuity (albeit in new forms) of fossilised assumptions and practices related to gender, social class and childcare. Nevertheless, within these changing times and settings we continued to carve out space and time for feminism.

Feminist academic practice can only be fully understood when explored at the local level, in relation to space-time and in connection to wider social relations and shifting political priorities. It is at the local level that the daily practices of higher education are carved out and where feminist approaches take a particular form. Through a focus on everyday academic practice it becomes possible to see where feminist approaches are explicit and where there are major concerns related to gender that are not sufficiently addressed (Smith 2001). It also becomes possible to see which feminist academic practices are valued by the higher education institution and which are not valued. Both space and time are co-implicated in the changing gendered relations of higher education and the ways that feminists practice their academic work (Massey 2005). These understandings further insight into how feminist approaches may be developed and strengthened in higher education. 


\section{References}

Adam, Barbara, 1990. Time and Social Theory. Cambridge: Polity.

Adam, Barbara, 1995. Timewatch. The Social Analysis of Time. Cambridge: Polity Press.

Adam, B. 2001. University Quality Audits - Echoes of a Darker Past. Sociology Network May

Adam, B. 2002. The Gendered Time Politics of Globalization: of Shadowlands and Elusive Justice. Feminist Review 70: 3-29.

Adam, B. 2003. Reflexive Modernization Temporalized. Theory Culture and Society $20,2,59-78$.

Adam, B. 2006. Time. Theory Culture and Society 23, 2-3: 119-138.

Black, P. 2005. Class Matters in UK Higher Education. Women's Studies International Forum 28, 2-3: 127 - 138.

Bourdieu, Pierre, Jean-Claude Chambordon and Jean-Claude Passeron, 1968/1991. The Craft of Sociology. Epistemological Preliminaries. New York: Walter de Gruyter. 
Cameron, Claire, 2004. Building an integrated workforce for a long term vision of universal early education and care. Daycare Trust, Leading the Vision, Policy Papers no. 3.

Cameron, C, Mooney, A. and Moss, P. 2002. The childcare workforce: current conditions and future directions. Critical Social Policy 22, 4: 572-595.

Coppock, Vicky, Deena Haydon and Ingrid Richter, 1995. The Illusions of 'PostFeminism' New Women, Old Myths. London: Taylor and Francis.

Davies, Karen, 1990. Women and Time. The Weaving of the Strands of Everyday Life. Aldershot: Avebury.

Edwards, Rosalind, 1993. Mature Women Students. Separating or Connecting Family and Education. London: Taylor and Francis.

Freire, Paulo, 1972. Cultural Action for Freedom. Harmondsworth: Penguin. Haug, Frigga, 1992. Beyond Female Masochism. Memory - Work and Politics. London: Verso.

Habermas, Jurgen, 1981/1987. Volume Two - Lifeworld and System: the Theory of Communicative Action. The Critique of Functionalist Reason. Cambridge: Polity. Henry, M. 2007. If the Shoe Fits: Authenticity, Authority and Agency. Feminist Diasporic Research. Women's Studies International Forum 30, 1: 70-80. Hill Collins, Patricia, 1990. Black Feminist Thought. Knowledge, Consciousness and the Politics of Empowerment. London: Unwin Hyman. 
Jaques, Elliot, 1982/1990. The Enigma of Time. In The Sociology of Time. ed. John Hassard, London: Macmillan.

Kristeva, J. Jardine, A. and Blake, H. 1981. Women's Time Signs 7, 1: 13-35.

Lefebvre, Henri, 1991. The Production of Space. Oxford: Blackwell.

Lewis, J. (2003) Developing Early Years Childcare in England, 1997-2002: The Choices for [Working] Mothers Social Policy and Administration 30, 3: 219-238.

Link, Rosemary and Anthony Bibus with Karen Lyons 2000. When Children Pay. US Welfare Reform and its implications for UK Policy. London: Child Poverty Action Group.

Massey, Doreen, 2005. For Space. London: Sage.

Moss, D. and Pryke, J. 2007. Creating Space and Time for Feminist Approaches in Higher Education. Women's Studies International Forum_30, 5 pp 367 - 379.

Moss, D. 2009. Changing times of feminism and higher education: from community to employability. Paper presented at the Symposium on Time, Work, Education, February $17^{\text {th }}$ to $19^{\text {th }}$ at Middlesex University.

Moss, D. 2002. Creating Space and Time to Study: Women in Higher Education. PhD., Leeds Metropolitan University.

Moss, Dorothy 2006. Gender, Space and Time: Women and Higher Education. Washington: Lexington, Rowman and Littlefield. 
Moss, D. and Pryke, J. 2004. Feminist Academics: Mediating Space and Time' Paper presented to Women in Higher Education Network Conference, ReInventing Academic Culture/Harmonizing Life and work: Provisioning for Survival, Excellence and Social Purpose on $14^{\text {th }}$ May at Bolton Institute of HE.

Moss, P. (2006) Structures, understandings and discourses: Possibilities for revisioning the early childhood worker. Contemporary Issues in Early Childhood 7, 1: $30-41$

Osgood, J. 2005. Who Cares? The Classed Nature of Childcare? Gender and Education 17, 3: 289-303

Smith, Dorothy E. 2002. Institutional Ethnography in Qualitative Research in Action ed. T. May London, Sage.

Wolf, A. Jenkins, A. and Vignoles, A. 2006. Certifying the Workforce: Economic Imperative or Failed Social Policy? Journal of Education Policy 21, 5: 535-565. Ylijoki, O-H. 2009. Acceleration of time in academia. Paper presented at the Symposium on Time, Work, Education, $17^{\text {th }}$ to $19^{\text {th }}$ February at Middlesex University.

\footnotetext{
${ }^{1}$ Extended versions of the research reflections from 2002 also appear in Moss and Pryke (2007).

${ }^{2}$ The name of the courses has been changed

${ }^{3}$ The names of the departments have been changed

${ }^{4}$ The names of all students have been changed.
} 